\title{
Combination of chemotherapy and mild hyperthermia enhances the anti-tumor effects of cisplatin and adriamycin in human bladder cancer T24 cells in vitro
}

\author{
YOUKO ITOH $^{1}$, YOSHIAKI YAMADA ${ }^{1}$, YOSHIAKI KAZAOKA ${ }^{2}$, \\ TSUNEO ISHIGUCHI $^{3}$ and NOBUAKI HONDA ${ }^{1}$ \\ Departments of ${ }^{1}$ Urology, ${ }^{2}$ Oral and Maxillofacial Surgery, and ${ }^{3}$ Radiology, \\ Aichi Medical University School of Medicine, Aichi 480-1195, Japan
}

Received September 28, 2009; Accepted November 9, 2009

DOI: $10.3892 /$ etm_00000049

\begin{abstract}
Although the combined effects of hyperthermia and chemotherapy for cancer therapy have been theoretically established, combination therapy with hyperthermia is not widely used clinically, since the application of hyperthermia is complex and maintaining a tumor temperature of $43^{\circ} \mathrm{C}$ or above is very difficult. Thus, in the present study, the combined effects of chemotherapy and mild hyperthermia, which is easier to apply than hyperthermia, were examined using a human bladder cancer cell line, T24. T24 cells were incubated at $37-47^{\circ} \mathrm{C}$ for $0-5 \mathrm{~h}$, and the survival rate of cells was measured using the MTT method. Cisplatin and adriamycin, which are indicated for human bladder cancer, were used as anti-tumor drugs. In the combination experiment, T24 cells were treated with cisplatin $(20$ and $200 \mu \mathrm{g} / \mathrm{ml})$ or adriamycin (4 and $40 \mu \mathrm{g} / \mathrm{ml}$ ) at $41^{\circ} \mathrm{C}$ for $0-5 \mathrm{~h}$ and at $37^{\circ} \mathrm{C}$ for $7-12 \mathrm{~h}$. After a total incubation of $12 \mathrm{~h}$, cell survival was measured by the MTT method. i) T24 cells, like cells in general, survived mild hyperthermia at $41^{\circ} \mathrm{C}$, but were killed at over $43^{\circ} \mathrm{C}$. ii) Although a low concentration $(20 \mu \mathrm{g} / \mathrm{ml})$ of cisplatin or of mild hyperthermia at $41^{\circ} \mathrm{C}$ did not affect the survival rate of T24 cells, this combination therapy decreased the survival rate of T24 cells with increasing incubation times at $41^{\circ} \mathrm{C}$. The anti-tumor effect of the combination of $20 \mu \mathrm{g} / \mathrm{ml}$ cisplatin and $41^{\circ} \mathrm{C}$ for $5 \mathrm{~h}$ was the same as that of 10 times the concentration (200 $\mu \mathrm{g} / \mathrm{ml})$ of cisplatin. iii) Adriamycin showed the same effects as cisplatin. The anti-tumor effect of the combination of $4 \mu \mathrm{g} / \mathrm{ml}$ adriamycin and $41^{\circ} \mathrm{C}$ for $5 \mathrm{~h}$ was identical to the anti-tumor effect of a 10-fold higher concentration $(40 \mu \mathrm{g} /$ $\mathrm{ml}$ ) of adriamycin. Based on these results, combination
\end{abstract}

Correspondence to: Dr Youko Itoh, Department of Urology, Aichi Medical University School of Medicine, 21 Nagakute-cho, Aichi-gun, Aichi 480-1195, Japan

E-mail: itoh@aichi-med-u.ac.jp

Key words: mild hyperthermia, combined effect, anti-tumor drug, chemotherapy, human bladder cancer cells with mild hyperthermia may enable a reduction in the dose of anti-tumor drugs. It was suggested that the side effects of chemotherapy could be reduced clinically by combining the drugs with mild hyperthermia. Mild hyperthermia might be a useful and practical heating method which could lead to the increased clinical applications of hyperthermia. We previously reported the preliminary results of M-VAC chemotherapy (methotrexate, vinblastine, doxorubicin and cisplatin) combined with mild hyperthermia, a new therapeutic strategy for advanced or metastatic transitional cell carcinoma of the urothelium. This basic research strongly supports the clinical beneficial results of chemotherapy combined with mild hyperthermia.

\section{Introduction}

Among urological cancers, the incidence of bladder cancer is the highest, and that in men is approximately 2.5 times higher than that in women. Approximately $95 \%$ of bladder cancers are urothelial carcinoma. The peak of incidence occurs in the 60-70 year age group, while there are few young patients with this disease under 50 years of age. The response rate of treatment for advanced metastatic transitional cell carcinoma is approximately $40 \%$, in spite of M-VAC chemotherapy (methotrexate, vinblastine, doxorubicin and cisplatin), the gold standard treatment $(1,2)$. Particularly in the case of metastasis to lymph nodes and other organs, the survival rate is low, 20\%. There are many reasons for the low response and survival rates. Since elderly patients cannot tolerate anti-tumor drugs, the dose intensity must be decreased (3). Continued administration of anti-cancer drugs becomes difficult due to the physical and mental distress caused by their severe side effects (4).

The efficacy of hyperthermia in combination with chemotherapy has been established experimentally and clinically $(5,6)$. Although chemotherapy is used at all medical institutions, very few institutions employ it in combination with hyperthermia.

The use of hyperthermia is not widespread at many medical facilities, due to the difficulty of heating and maintaining tissues at a temperature of $43^{\circ} \mathrm{C}$ or higher. Additionally, the 
costs of the devices used for applying clinical hyperthermia along with the associated personnel costs are high.

Thus, the effects of mild hyperthermic heating at a lower temperature of $41^{\circ} \mathrm{C}$ were examined in contrast to hyperthermia at temperatures of $43^{\circ} \mathrm{C}$ or higher. The temperature used for mild hyperthermia is not sufficiently high enough to kill tumor cells, but it is relatively easy to heat and maintain cells and tissue at $41^{\circ} \mathrm{C}$. In addition, mild hyperthermia is a less severe therapy for cancer patients than standard hyperthermia.

We previously reported that the cytotoxic effects of antitumor drugs were increased by combining anti-tumor drugs (adriamycin, vincristine) with mild hyperthermia using the NALM-6 leukemia cell line, and confirmed the effectiveness of mild hyperthermia (7).

In this experiment, using a human bladder cancer cell line, the combined effect of mild hyperthermia with cisplatin and adriamycin was examined. These drugs are the main antitumor drugs in the M-VAC chemotherapeutic regimen, which is the typical standard therapy for progressive urothelial cancer.

\section{Materials and methods}

Cell line. T24 cells, a human bladder cell line, were cultured in RPMI-1640 culture medium including 10\% FCS and were used in experiments during the log phase of growth. T24 cells were sown on 96 -well plates at $5 \times 10^{4} / 0.2 \mathrm{ml}$ culture medium/ well. These plates were used for experiments after one day in a $\mathrm{CO}_{2}$ incubator at $37^{\circ} \mathrm{C}$.

Cell survival rate. The cell survival rate was measured by the 3-[4,5-dimethylthiazol-2-yl]-2,5-diphenyl tetrazolium bromide (MTT) method (Cell Proliferation Kit; Roche Diagnostics, Mannheim, Germany) (8). After cell treatment, MTT reagent was added $(1 / 10)$ to the cell reaction medium. Following incubation at $37^{\circ} \mathrm{C}$ for $2 \mathrm{~h}$, the same volume of $10 \%$ SDS was added to the reaction medium. The absorbance at $550 \mathrm{~nm}$ was measured.

Thermal sensitivity of the human bladder cancer T24 cell line. T24 cells in 96-well plates were incubated for $0-5 \mathrm{~h}$ at 37 , $39,41,43,45$ and $47^{\circ} \mathrm{C}$, respectively, with a device capable of maintaining very precise temperatures (temperature accuracy $\pm 0.01^{\circ} \mathrm{C}$; Nihon Kouseikagaku Res. Co., Osaka, Japan). The survival rate of cells was measured by the MTT method.

Response of human bladder cancer T24 cells to anti-tumor drugs. Cisplatin (CDDP) and adriamycin (ADR) are typical carcinostatics for the treatment of bladder cancer with M-VAC chemotherapy. These two anti-tumor drugs were used in combination with mild hyperthermia, and the anti-tumor effect on human bladder cancer T24 cells was examined. In the combination experiment with carcinostatics and mild hyperthermia, human bladder cancer T24 cells were treated with final CDDP concentrations of 20 and $200 \mu \mathrm{g} / \mathrm{ml}$ or ADR concentrations of 4 and $40 \mu \mathrm{g} / \mathrm{ml}$ at $41^{\circ} \mathrm{C}$ for $0-5 \mathrm{~h}$. Total incubation time (at both 41 and $37^{\circ} \mathrm{C}$ ) of all samples was $12 \mathrm{~h}$. After $12 \mathrm{~h}$, the MTT reagent was added to the incubation medium, and the cell survival rate was measured. For example, when

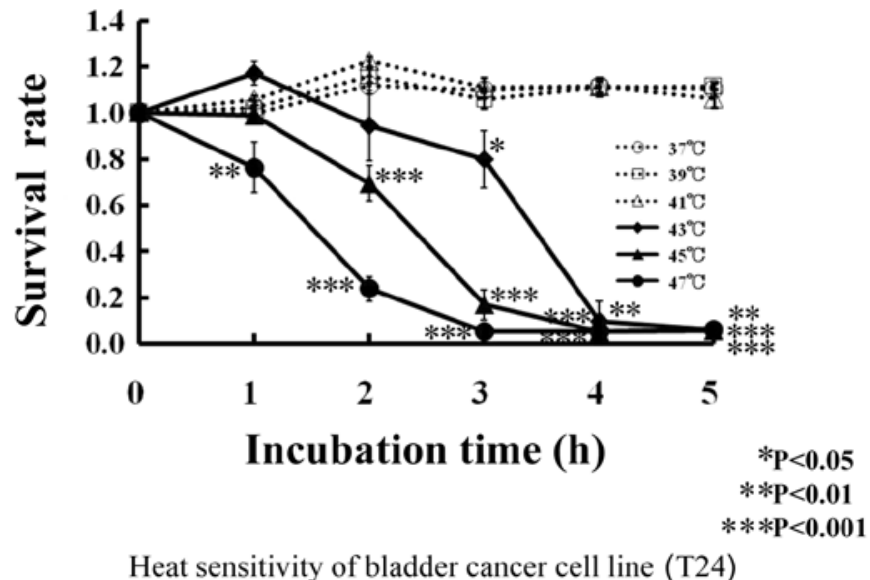

Figure 1. Thermal sensitivity of human bladder cancer cell line, T24s. T24 cells were incubated at $37^{\circ} \mathrm{C}(--\circ--), 39^{\circ} \mathrm{C}(----), 41^{\circ} \mathrm{C}(--\triangle--), 43^{\circ} \mathrm{C}(\bullet)$, $45^{\circ} \mathrm{C}(\Delta)$ or $47^{\circ} \mathrm{C}(\bullet)$ for $0,1,2,3,4$ and $5 \mathrm{~h}$, respectively. Viability of T24 cells was measured by the MTT method after incubation. ${ }^{*} \mathrm{P}<0.05,{ }^{* *} \mathrm{P}<0.01$ and ${ }^{* * *} \mathrm{P}<0.001$ compared to $0 \mathrm{~h}$ of incubation at $37^{\circ} \mathrm{C}$.

samples were treated at $41^{\circ} \mathrm{C}$ for $3 \mathrm{~h}$, they were incubated at $37^{\circ} \mathrm{C}$ in a $\mathrm{CO}_{2}$ incubator for $9 \mathrm{~h}$.

\section{Results}

Thermal sensitivity of human bladder cancer cells. As shown in Fig. 1, almost all (1.0) the human bladder cancer T24 cells survived at 37,39 and $41^{\circ} \mathrm{C}$ after $5 \mathrm{~h}$ of incubation. With treatment at $43^{\circ} \mathrm{C}$, the survival rate of T24 cells was 0.94 after $2 \mathrm{~h}$ of incubation, 0.8 after $3 \mathrm{~h}$ and $0.06-0.09$ after $4-5 \mathrm{~h}$. At $45^{\circ} \mathrm{C}$, the survival rate of T24 cells was 0.69 after $2 \mathrm{~h}$ of incubation, 0.17 after $3 \mathrm{~h}$ and 0.05 after $4-5 \mathrm{~h}$. At $47^{\circ} \mathrm{C}$, the survival rate of T2 4 cells decreased linearly to 0.05 after $3 \mathrm{~h}$ of incubation.

Human bladder cancer T24 cells were not influenced by the thermal effect of $41^{\circ} \mathrm{C}$, and cell death was noted from $43^{\circ} \mathrm{C}$, just as with cells in general.

Sensitivity of human bladder cancer T24 cells to anti-tumor drugs. The sensitivity of T24 cells to CDDP $(0,2$ and $20 \mu \mathrm{g} /$ $\mathrm{ml}$ ) is shown by the survival rate (y-axis) at $0 \mathrm{~h}$ of incubation at $41^{\circ} \mathrm{C}\left(12-\mathrm{h}\right.$ incubation at $\left.37^{\circ} \mathrm{C}\right)$ (Fig. 2). The survival rate of T24 cells in CDDP $(0 \mu \mathrm{g} / \mathrm{ml})$ after $12 \mathrm{~h}$ of incubation at $37^{\circ} \mathrm{C}$ (without mild hyperthermia) was 1.0. Additionally, the survival rate of T24 cells at a low concentration $(20 \mu \mathrm{g} / \mathrm{ml})$ of CDDP was 1.0, and that at a high concentration $(200 \mu \mathrm{g} / \mathrm{ml})$ of CDDP was $0.62(\mathrm{P}<0.01)$.

The sensitivity of T24 cells to ADR is shown by the survival rate (y-axis) at $0 \mathrm{~h}$ of incubation at $41^{\circ} \mathrm{C}$ (Fig. 3). Similar to CDDP, the survival rate at a low concentration $(4 \mu \mathrm{g} / \mathrm{ml})$ of ADR was 1.0 and that at a high concentration $(40 \mu \mathrm{g} / \mathrm{ml})$ of ADR decreased the survival to $0.72(\mathrm{P}<0.01)$.

Combination of anti-tumor drugs and mild hyperthermia. The survival rate of T24 cells with a combination of antitumor drugs and mild hyperthermia is shown in Figs. 2 and 3. As shown in Fig. 1, regarding thermal sensitivity, the survival rate of T24 cells was not altered by mild hyperthermia at $41^{\circ} \mathrm{C}$ 


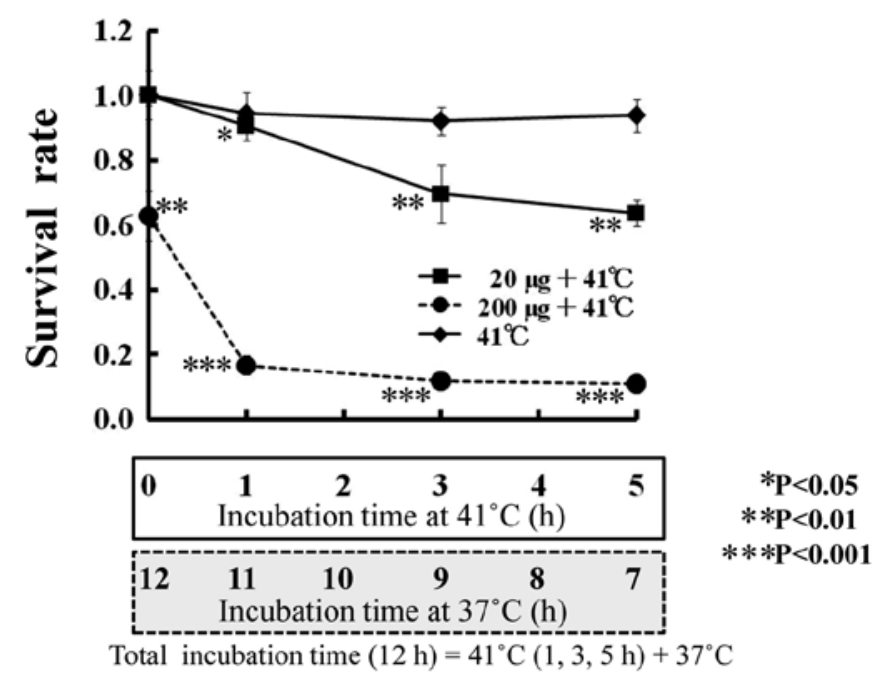

Survival rate of T24 cells (bladder cancer cell line) with cisplatin + mild hyperthermia $\left(41^{\circ} \mathrm{C}\right)$

Figure 2. Effects of the anti-tumor drug CDDP in combination with mild hyperthermia at $41^{\circ} \mathrm{C}$ on the T24 human bladder cancer cell line. T24 cells were incubated with CDDP $[20 \mu \mathrm{g} / \mathrm{ml}(\mathbf{\square})$ or $200 \mu \mathrm{g} / \mathrm{ml}(--\bullet--)]$ at 41 and $37^{\circ} \mathrm{C}$, respectively. Cells were incubated at $41^{\circ} \mathrm{C}$ (mild hyperthermia) ( for $0,1,3$ and $5 \mathrm{~h}$, and then incubated at $37^{\circ} \mathrm{C}$. Total incubation time at 41 and then $37^{\circ} \mathrm{C}$ was $12 \mathrm{~h}$. After incubation for $12 \mathrm{~h}$, the cell viability of the T24 cells was measured by the MTT assay. ${ }^{*} \mathrm{P}<0.05,{ }^{* *} \mathrm{P}<0.01$ and ${ }^{* * *} \mathrm{P}<0.001$ compared to $0 \mathrm{~h}$ of incubation at $41^{\circ} \mathrm{C}$.

for $5 \mathrm{~h}$; nor was it altered by anti-tumor drugs, such as a low CDDP concentration $(2 \mu \mathrm{g} / \mathrm{ml})$ for $12 \mathrm{~h}$ (Fig. 2). However, the survival rate decreased with a combination of mild hyperthermia at $41^{\circ} \mathrm{C}$ and a low concentration of anti-tumor drugs (CDDP $20 \mu \mathrm{g} / \mathrm{ml}$ or ADR $4 \mu \mathrm{g} / \mathrm{ml}$ ).

Mild hyperthermia at $41^{\circ} \mathrm{C}$ or a low concentration of antitumor drugs CDDP and ADR had no independent influence on the survival of T24 cells. The viability of T24 cells was decreased from 1.0 to $0.90(\mathrm{P}<0.05), 0.70(\mathrm{P}<0.01)$ and 0.63 $(\mathrm{P}<0.01)$ by the combination of mild hyperthermia at $41^{\circ} \mathrm{C}$ and $20 \mu \mathrm{g} / \mathrm{ml} \mathrm{CDDP}$ for $0,1,3$ and $5 \mathrm{~h}$, respectively. The viability of T24 cells was 0.62 at a CDDP concentration of $200 \mu \mathrm{g} /$ $\mathrm{ml}$ without mild hyperthermia. Therefore, the viability of T24 cells at a CDDP concentration of $20 \mu \mathrm{g} / \mathrm{ml}$ with mild hyperthermia at $41^{\circ} \mathrm{C}$ for $5 \mathrm{~h}$ had the same anti-tumor effect as a 10 -fold higher ADR concentration $(200 \mu \mathrm{g} / \mathrm{ml})$.

The viability of T24 cells with $200 \mu \mathrm{g} / \mathrm{ml}$ CDDP was decreased from 0.62 to $0.16(\mathrm{P}<0.001)$ in combination with mild hyperthermia at $41^{\circ} \mathrm{C}$ for $1 \mathrm{~h}$, and to $0.11(\mathrm{P}<0.001)$ at $41^{\circ} \mathrm{C}$ for $3 \mathrm{~h}$. The addition of mild hyperthermia at $41^{\circ} \mathrm{C}$ for $1 \mathrm{~h}$ quadrupled the anti-tumor activity of CDDP $(200 \mu \mathrm{g} / \mathrm{ml})$.

As with CDDP, the viability of T24 cells with $4 \mu \mathrm{g} / \mathrm{ml}$ ADR was decreased from 1.0 to $0.83(\mathrm{P}<0.05), 0.70(\mathrm{P}<0.01)$ and $0.69(\mathrm{P}<0.01)$ in combination with mild hyperthermia at $41^{\circ} \mathrm{C}$ for $0,1,3$ and $5 \mathrm{~h}$, respectively. Viability of T24 cells with $40 \mu \mathrm{g} / \mathrm{ml}$ ADR was 0.72 . Therefore, the cell viability when $4 \mu \mathrm{g} / \mathrm{ml}$ ADR was combined with mild hyperthermia at $41^{\circ} \mathrm{C}$ for $3 \mathrm{~h}$ showed the same anti-tumor effect as a 10 -fold higher ADR concentration $(40 \mu \mathrm{g} / \mathrm{ml})$.

The viability of T24 cells with $40 \mu \mathrm{g} / \mathrm{ml}$ ADR decreased from 0.72 to $0.33(\mathrm{P}<0.001)$ when combined with mild hyperthermia at $41^{\circ} \mathrm{C}$ after $1 \mathrm{~h}$, and to $0.10(\mathrm{P}<0.001)$ at $41^{\circ} \mathrm{C}$

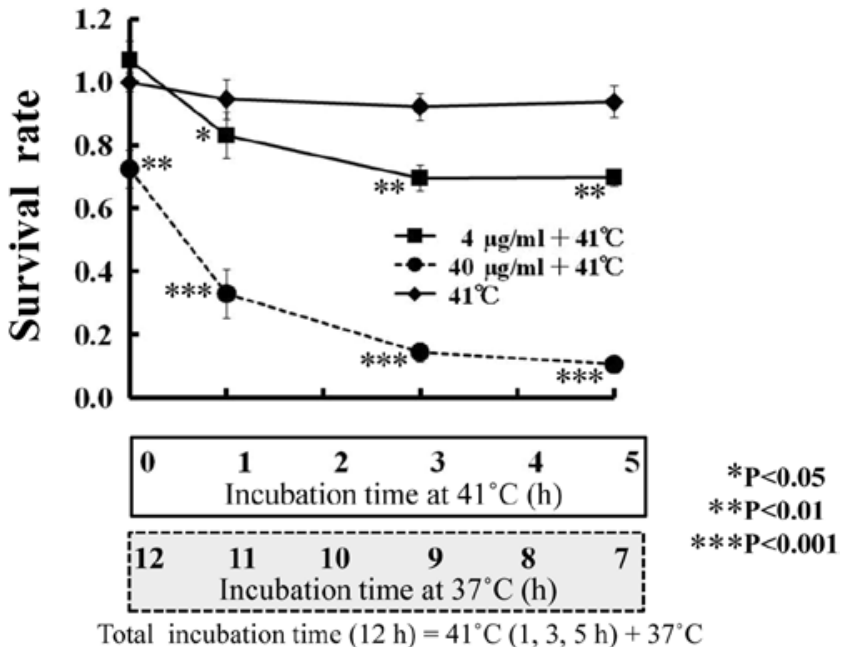
Survival rate of T24 cells (bladder cancer cell line)
with adriamycin + mild hyperthermia $\left(41^{\circ} \mathrm{C}\right)$

Figure 3. Effects of the anti-tumor drug ADR in combination with mild hyperthermia at $41^{\circ} \mathrm{C}$ on the T24 human bladder cancer cell line. T24 cells were incubated with ADR [ $4 \mu \mathrm{g} / \mathrm{ml}(\mathbf{m})$ or $40 \mu \mathrm{g} / \mathrm{ml}(----)]$ at 41 and $37^{\circ} \mathrm{C}$, respectively. Cells were incubated at $41^{\circ} \mathrm{C}$ (mild hyperthermia) ( $\bullet$ ) for $0,1,3$ and $5 \mathrm{~h}$, and then incubated at $37^{\circ} \mathrm{C}$. Total incubation time at 41 and then $37^{\circ} \mathrm{C}$ was $12 \mathrm{~h}$. After incubation for $12 \mathrm{~h}$, viability of the T24 cells was measured by the MTT assay. ${ }^{*} \mathrm{P}<0.05,{ }^{* *} \mathrm{P}<0.01$ and ${ }^{* * * *} \mathrm{P}<0.001$ compared to $0 \mathrm{~h}$ of incubation at $41^{\circ} \mathrm{C}$.

after $5 \mathrm{~h}$. The addition of mild hyperthermia at $41^{\circ} \mathrm{C}$ for $1 \mathrm{~h}$ caused a 2.2-fold increase in the anti-tumor activity of $40 \mu \mathrm{g} /$ $\mathrm{ml}$ ADR.

\section{Discussion}

Hyperthermia as a cancer therapy requires heating to $43^{\circ} \mathrm{C}$ or higher in order to kill tumor cells. However, it is technically difficult to heat and maintain some organs and tissues at that temperature. Mild hyperthermia is easy, safe and cost-effective, and can be practically performed at any medical facility.

We previously reported that mild hyperthermia at $41^{\circ} \mathrm{C}$ was effective in combination with chemotherapy, instead of hyperthermia at $43^{\circ} \mathrm{C}$, in an in vitro experiment using a leukemia cell line NALM-6 (7). Mild hyperthermia markedly enhanced the anti-tumor effects of anti-tumor drugs.

M-VAC chemotherapy (methotrexate, vinblastine, doxorubicin and cisplatin) is the gold standard therapy for transitional cell carcinoma of the urothelium $(1,2)$. However, M-VAC chemotherapy is associated with severe adverse drug reactions, such as renal damage, bone marrow depression and gastrointestinal toxicity (nausea and vomiting) $(3,4)$. In addition, its response rate is not always high, at about $40 \%$. We examined whether the anti-tumor effect in the leukemic cell line could be extended to transitional cell carcinoma of the urothelium by combining mild hyperthermia with M-VAC chemotherapy in an in vitro experiment. In this experiment, the anti-tumor effects of CDDP and ADR, which have the main target action in M-VAC chemotherapy, were examined using the human bladder cancer cell line T24.

The thermal sensitivity of T24 cells was the same as that of cells in general. The survival rate of T24 cells was not 
altered by mild hyperthermia at $41^{\circ} \mathrm{C}$, and was decreased by heating at over $43^{\circ} \mathrm{C}$.

CDDP and ADR are well-known anti-tumor drugs in M-VAC chemotherapy for transitional cell carcinoma of the urothelium (1-4). The survival rate of T24 cells was not affected by a low CDDP concentration $(20 \mu \mathrm{g} / \mathrm{ml})$ or mild hyperthermia at $41^{\circ} \mathrm{C}$, independently. However, the survival rate was significantly decreased by a low CDDP concentration $(20 \mu \mathrm{g} / \mathrm{ml})$ in combination with mild hyperthermia at $41^{\circ} \mathrm{C}$ according to the incubation time. The anti-tumor effect of a low CDDP concentration $(20 \mu \mathrm{g} / \mathrm{ml})$ and $41^{\circ} \mathrm{C}$ for $5 \mathrm{~h}$ resulted in the same survival rate as that of a 10 -fold higher concentration $(200 \mu \mathrm{g} / \mathrm{ml})$ of CDDP.

As with CDDP, another anti-tumor drug, ADR, showed the same effects. The anti-tumor effect of $4 \mu \mathrm{g} / \mathrm{ml} \mathrm{ADR}$ at $41^{\circ} \mathrm{C}$ for $3 \mathrm{~h}$ achieved the same survival rate as a 10-fold higher ADR concentration $(40 \mu \mathrm{g} / \mathrm{ml})$.

Based on these results, a low concentration of anti-tumor drugs that have no tumor cell killing effect would be expected to have a 10 times greater anti-tumor effect in combination with mild hyperthermia at $41^{\circ} \mathrm{C}$. Given that, at the same concentration of anti-tumor drugs, the anti-tumor effect of $200 \mu \mathrm{g} / \mathrm{ml} \mathrm{CDDP}$ increased 4-fold $(\mathrm{P}<0.001)$ and the effect of $40 \mu \mathrm{g} / \mathrm{ml} \mathrm{ADR}$ increased 2.2-fold $(\mathrm{P}<0.001)$ in combination with mild hyperthermia at $41^{\circ} \mathrm{C}$ for $1 \mathrm{~h}$, the increase in tumor cell killing activity of anti-tumor drugs by combination with mild hyperthermia was confirmed.

It is reported that CDDP combines with the DNA strand in cancer cells and inhibits the DNA synthesis and cell division of cancer cells (9). The mechanism of the anti-tumor effect of ADR is the inhibition of both DNA and RNA synthesis after ADR forms a complex with DNA in tumor cells and inhibits both DNA polymerase and RNA polymerase reactions $(10,11)$.

It seems that combination with mild hyperthermia potentiated the cytotoxic effects of these anti-tumor drugs by inducing apoptosis. Kameda et al reported that apoptosis was significantly enhanced when mild hyperthermia was combined with an anti-tumor drug (12).

Hyperthermia was found to inhibit the repair of DNA damage by anti-tumor drugs and radiation and increased the anti-tumor activity of chemotherapy and radiotherapy (13). Shioura et al (14) and Kano et al (15) reported an increase in the cytotoxic effects of combined treatment with low hyperthermia $\left(40^{\circ} \mathrm{C}\right)$ and bleomycin in vitro. Ono et al also reported that mild hyperthermia increased blood flow and enhanced the uptake of anti-tumor drugs into tumor tissue (16). Furthermore, mild hyperthermia was more effective in promoting heat-mediated suicide-gene (HSP 70) expression than high temperature therapy (17). Mild temperatures below $41^{\circ} \mathrm{C}$ showed significantly smaller energies in Arrhenius plots for some anti-tumor drugs than those observed with temperatures above $41^{\circ} \mathrm{C}$ (18). Recently, Ahmed et al reported mild hyperthermia- and hyperthermia-induced enhancement of drug cytotoxicity in apoptosis (19).

From these reports, it was suggested that mild hyperthermia enhances apoptosis and the anti-tumor effects of chemotherapy through an increase in the uptake of carcinostatics into tumor cells, and inhibits the repair of tumor cell killing by anti-tumor drugs.
These experimental results indicate the possibility that the dose of anti-tumor drugs can be decreased by combination with mild hyperthermia, thus reducing the side effects of the drugs. In poorly effective chemotherapy, a higher response rate is expected by combination with mild hyperthermia.

We found clinically mild hyperthermia to be safe, costeffective and easy to perform using a far-infrared apparatus $(20,21)$. With the approval of the ethics committee of our University, combination therapy with mild hyperthermia and chemotherapy for progressive bladder cancer was performed with exceptional results $(22,23)$. We previously reported that combination therapy with mild hyperthermia and M-VAC chemotherapy (methotrexate, vinblastine, doxorubicin and cisplatin) reduces gastrointestinal side effects and potentiates the anti-tumor effect, with an excellent response rate of $83 \%$ for advanced or metastatic transitional cell carcinoma of the urothelium (24). This basic in vitro research strongly supports our clinical results.

\section{References}

1. Sternberg CN, Yagoda A, Scher HI, et al: Preliminary results of M-VAC (methotrexate, vinblastine, doxorubicin and cisplatin) for transitional cell carcinoma of the urothelium. J Urol 133: 403-407, 1985

2. Masse HM, Hansen SW, Robert JT, et al: Gemcitabine and cisplatin versus methotrexate, vinblastine, doxorubicin and cisplatin in advanced or metastatic bladder cancer; results of a large, randomized, multinational, multicancer, phase III study. J Clin Oncol 18: 3068-3077, 2000.

3. Saxman SB, Propert KJ, Einborn LH, et al: Long-term follow-up of a phase III intergroup study of cisplatin alone or in combination with methotrexate, vinblastine and doxorubicin in patients with metastatic urothelial carcinoma; a cooperative group study. J Clin Oncol 15: 2564-2569, 1997.

4. Sternberg CN, Yagoda A, Scher HI, et al: Methotrexate, vinblastine, doxorubicin and cisplatin for advanced transitional cell carcinoma of the urothelium. Efficacy and patterns of response and relapse. Cancer 64: 2448-2458, 1989.

5. Mizuno S: Biological and medical grounds of combination with hyperthermia and radiotherapy. In: Hyperthermia Manual (in Japanese). Matsuda T (ed). Magupuros Publication Co., pp1-5, 1991.

6. Mitsuhashi N: Positioning in combination therapy and future subjects. In: Hyperthermia - Guide Book of Hyperthermia for Cancer Therapy (in Japanese). Japanese Society for Thermal Medicine, Mainichi-kenkousaron Publication Co., pp6-7, 2008.

7. Itoh Y, Kazaoka Y, Nitta M, et al: Combining anti-tumor drugs with mild hyperthermia increases the cytotoxic effects of drugs on human leukemia cells in vitro. Mol Med Rep 2: 411-415, 2009.

8. Mosmann T: Rapid colorimetric assay for cellular growth and survival: application to proliferation and cytotoxicity assays. J Immunol Methods 65: 55-63, 1983.

9. Zwelling LA and Kohn KW: Mechanism of action of cis-dichlorodiammineplatinum (II). Cancer Treat Rep 63: 1439-1444, 1979.

10. Di M: Adriamycin (NSC-123127): mode and mechanism of action. Cancer Chemother Rep 6: 91-106, 1975.

11. Nemoto T and Takahira H: Uptake of adriamycin into the cells and the interaction with DNA. Yakugakuzasshi (in Japanese) 93: 1498-1508, 1973.

12. Kameda K, Kondo T, Tanabe K, et al: The role of intracellular $\mathrm{Ca}^{2+}$ in apoptosis induced by hyperthermia and its enhancement by verapamil in U937 cells. Int J Radiat Oncol 49: 1369-1379, 2001.

13. Hall EJ and Roizin T: Biological effects of heat. Cancer Res 44: S4708-S4713, 1984.

14. Shioura H, Hayashi S, Matsumoto $\mathrm{H}$, et al: The effects of combined treatments with low hyperthermia and bleomycin on survival of murine L cells. Clin Cancer Res 16: 147-152, 1997.

15. Kano E, Furukawa-Furuya M and Nitta K: Sensitivity of bleomycin-resistant variant cells enhanced by $40^{\circ} \mathrm{C}$ hyperthermia in vitro. Int J Hyperthermia 4: 5547-5553, 1988. 
16. Ono H, Ando S and Suzuki T: The drug uptake in the tumor with the mild-hyperthermia treatment in combination with the chemotherapy in vivo. Jpn J Hyperthermic Oncol 22: 23-33, 2006.

17. Huang Q, Hu JK and Lohr F: Heat-induced gene expression as a novel targeted cancer gene therapy strategy. Cancer Res 60: 3435-3439, 2000.

18. Urano M, Kuroda M and Nishimura Y: For the clinical application of thermal chemotherapy given at mild temperatures. Int $\mathrm{J}$ Hyperthermia 15: 79-107, 1999.

19. Ahmed K, Hori T and Yu DA: Hyperthermia chemo-sensitization, chemical thermo-sensitization and apoptosis. Thermal Med 24: $1-12,2008$.

20. Itoh Y, Tazawa K, Wada K, et al: Induction of HSP 70 in lymphocytes by whole body far-infrared hyperthermia. Jpn J Hyperthermic Oncol 21: 209-220, 2005.
21. Itoh Y, Ogawa K and Tazawa K: Improvement of athletic performances by heat shock protein 70 induced with mild hyperthermia. Jpn J Clin Physiol 38: 13-21, 2008.

22. Itoh Y and Yamada Y: Enhancement of the anti-tumor effects and improvement of QOL by the combination with mild hyperthermia. $67^{\text {th }}$ Annual Meeting of the Japanese Cancer Association (JCA 2008) - Proceedings, p361, 2008.

23. Yamada Y, Itoh Y and Honda Y: Increase of anti-tumor effect by combination therapy with mild hyperthermia and chemotherapy for bladder cancer. Thermal Med (in Japanese) 24: S65, 2008.

24. Yamada Y, Itoh Y, Aoki S, et al: Preliminary results of M-VAC chemotherapy combined with mild hyperthermia, a new therapeutic strategy for advanced or metastatic transitional cell carcinoma of the urothelium. Cancer Chemother Pharmacol 64 : 1079-1083, 2009. 